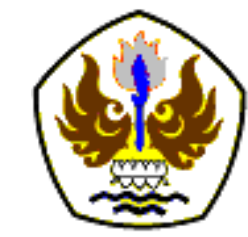

INFOMATEK

Volume 21 Nomor 2 Desember 2019

\title{
RANCANG BANGUN SISTEM PENGUKUR GAYA PADA MESIN WIRE DRAWING DENGAN MENGGUNAKAN LOAD CELL
}

\author{
Iman Dirja*), Oleh, M. Afif Fajar Ramadhan \\ Program Studi Teknik Mesin \\ Fakultas Teknik - Universitas Singaperbangsa Karawang
}

\begin{abstract}
Abstrak: Mesin wire drawing merupakan mesin yang berfungsi untuk proses pengecilan diameter kawat dengan cara menarik kawat tersebut dengan memasukan kedalam dies. Ketika proses penarikan kawat tersebut terjadi gaya penarikan yang menunjukan besarnya gaya yang diperlukan sehingga terjadi deformasi plastis.untuk mengetahui berapa besarnya gaya penarikan maka drancang dan dibuat alat untuk mengukur gaya tersebut dengan menggunakan load cell dan weight indicator. Load cell yang digunakan jenis PST yang mempunyai beban maksimum ketika digunakan sebesar $10.000 \mathrm{~N}$, sedangkan untuk menampilkan berapa gaya penarikan ditampilkan dengan alat weigth indicator. Alat pengukur gaya pada mesin wire drawing mempermudah dalam pembacaan hasil dari gaya penarikan karena langsung bisa dibaca, daya penarikan sekaligus bisa diketahui sehngga waktu pemakaian mesin lebih cepat. Hasil perancangan diperoleh bahwa dengan gaya tarik maksimum mesin wire drawing terdapat reduksi 19\%. Gaya tarik terbesar adalah 6.187,5 N.
\end{abstract}

Kata kunci: gaya tarik, load cell, wire drawing

\section{PENDAHULUAN}

Proses pembentukan logam sejak dulu dikenal dengan dua cara, yaitu secara hot working maupun cold working, kedua cara tersebut terdapat kelebihan dan kekurangan sehingga komponen yang akan dibuat disesuaikan dengan kebutuhan (Syarief [1]). Pada proses penarikan kawat (wire drawing) dilihat dari temperatur kerjanya termasuk kepada proses pengerjaan cold working karena dilakukan pada temperatur di bawah temperatur

\footnotetext{
*) imandirja28@yahoo.co.id

Pertama diterima : 18 Oktober 2019

Direvisi : 21 Oktober 2019

Disetujui untuk publikasi: 28 Oktober 2019
}

rekristalisasi material atau logam tersebut. Pada Proses ini terjadi gaya pembentukan secara deformasi plastis sehingga terjadi perubahan bentuk secara permanen (Asfarizal dkk. [2]). Gaya pembentukan ini berupa tekanan dan tarikan yang terjadi sewaktu benda kerja melewati dies, wire drawing diaplikasikan dalam pembuatan kabel, kawat, dan pipa (Setyadi dkk. [3]). Gambar 1 memperlihatkan skematis penarikan kawat.

Dalam proses penarikan kawat perlu diketahui gaya penarikan maupun daya penarikan untuk mengetahui sejauh mana kekuatan material tersebut ketika dilakukan proses penarikan. 
Diperlukan suatu alat bantu untuk membantu mengetahui gaya dan daya pembentukan tersebut, alat yang digunakan berupa load cell dan weight indicator yang disebut sebagai instrument pengukuran (Sari dkk. [4]). Jadi instrument adalah sesuatu yang digunakan untuk membantu mempermudah proses penarikan kawat untuk mengetahui gaya dan daya pembentukan logam.

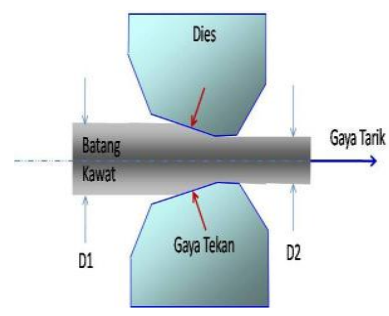

Gambar 1.

Skematis penarikan kawat

\section{METODOLOGI}

\subsection{Komponen Penelitian}

Komponen yang diperlukan untuk membuat alat pengukur gaya tarik pada mesin wire drawing adalah:

\section{Load cell}

Load cell banyak digunakan dalam mesinmesin yang memerlukan konversi satuan ke satuan lain sesuai dengan keperluan. Load cell dibentuk dari strain gauge yang berfungsi sinyal tahanan menjadi sinyal regangan sehingga bisa mengetahui perubahan defleksi yang terjadi pada saat proses penarikan kawat terjadi. dapat dilihat pada gambar) dibawah ini. Gambar 2 memperlihatkan salah satu load cell.

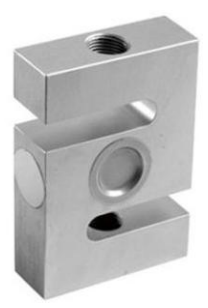

\section{Gambar 2.}

Load cell

Di dalam load cell terdapat beberapa komponen dan rangkaian yaitu di antaranya adalah strain gage. Strain gage berfungsi mengubah besarnya defleksi dan load cell. Strain gage merupakan lilitan kawat yang akan berubah sehingga defleksi yang terjadi akan diketahui berapa besarnya (Debriand dkk. [5]). Jenis strain gage yang digunakan dalam proses penarikan kawat dapat dilihat pada Gambar 3.

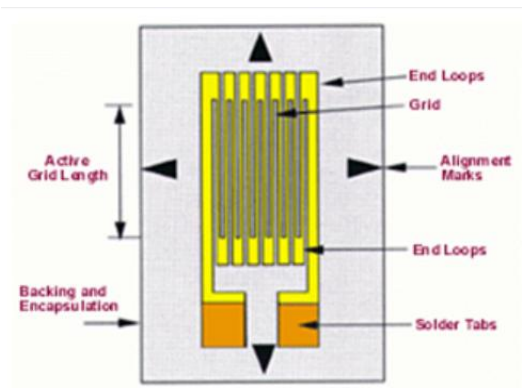

Gambar 3.

Strain Gage
Untuk menaikan sensitivitas load cell, maka strain gauge dirangkai dari beberapa buah menjadi susunan jembatan wheatstone. 


\section{Weight Indicator}

Weight indicator merupakan alat yang berfungsi untuk menampilkan besarnya gaya penarikan ketika mesin sedang melakukan proses penarikan. Alat ini dihubungkan dengan load cell.

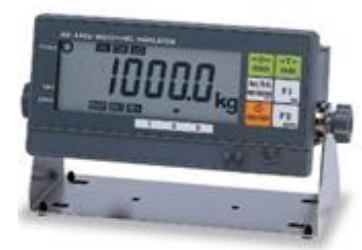

Gambar 4.

Weight Indicator

\subsection{Tahapan Pengerjaan}

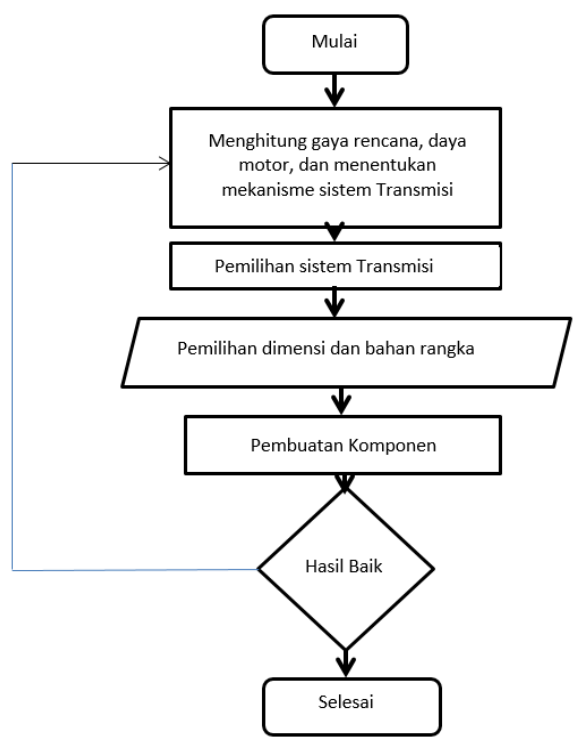

Gambar 5.

Diagram alir Rancang Bangun

\subsection{Kriteria Desain}

Kemampuan penarikan mesin wire drawing direncanakan bisa menggunakan material tembaga. Sebelum melakukan proses pembuatan mesin wire drawing perlu adanya kriteria desain terlebih dahulu. Kriteria desain ketika merancang mesin wire drawing adalah:

a. Gaya maksimum penarikan material tembaga dengan nilai koefisien pengerasan regangan $\mathrm{K}=320 \mathrm{MPa}$, $\mathrm{n}=0,54$

b. Arah gaya penarikan mesin wire drawing

c. Kapasitas beban maksimum load cell

d. Proses assembling

Hasil dari Identifikasi keinginan produsen menjadi salah satu kriterian perancangan dari mesin wire drawing ini, yaitu dikatakan baik atau tidak dengan batasan:
a. Aman dalam pemakaian
b. Mudah dioperasikan
c. Nyaman dalam pengoprasian
d. Mudah dalam perawatan.

\section{HASIL DAN PEMBAHASAN}

Gambar 6 memperlihatkan mesin wire drawing yang sudah terakit.

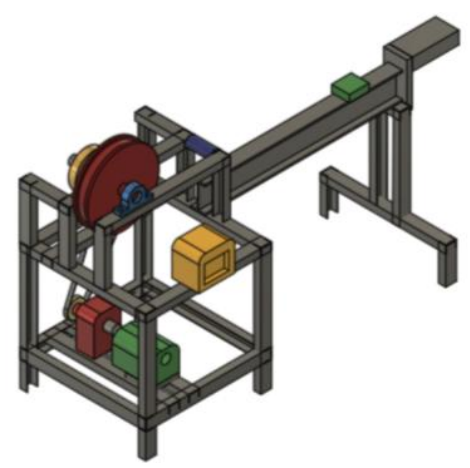

Gambar 6.

Mesin Wire Drawing 
Alat pengukur gaya (load cell) dipasang pada bagian belakang mesin yang dihubungkan dengan rol bagian kawat dipasangkan, kemudian dari load cell dihubungkan ke weight indicator sehingga gaya penarikan kawat bisa dibaca. Pengujian pada mesin wire drawing dengan menggunakan specimen tembaga $(\mathrm{K}=320 \mathrm{MPa} \mathrm{n}=0,54)$, dengan reduksi maksimum 19\%. Gambar 7 memperlihatkan sistem penarikan kawat menggunakan load cell.

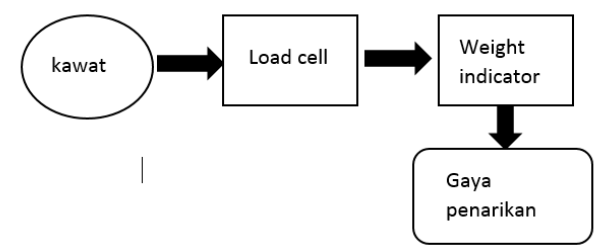

Gambar 7.

Sistem penarikan kawat menggunakan load cell

Nilai gaya Tarik terbesar adalah $6.187,5 \mathrm{~N}$, maka load cell yang digunakan ialah Load cell type-S PST dengan kapasitas beban maksimum $10.000 \mathrm{~N}$.

\section{KESIMPULAN}

Berdasarkan hasil penelitian, diperoleh bahwa Load cell yang digunakan pada mesin wire drawing berfungsi untuk mengetahui gaya tarik yang terjadi ketika proses penarikan kawat. Setelah mengetahui data hasil perhitungan percobaan, maka load cell dapat dipilih sesuai dengan gaya tarik maksimum mesin wire drawing pada saat melakukan pengujian dengan menggunakan specimen tembaga
( $\mathrm{K}=320 \mathrm{MPa} \quad \mathrm{n}=0,54)$, dengan reduksi maksimum $19 \%$. Sehingga didapat nilai gaya tarik terbesar adalah $6.187,5 \mathrm{~N}$, maka load cell yang digunakan ialah load cell type - S PST dengan kapasitas beban maksimum $10.000 \mathrm{~N}$. Untuk melihat besarnya gaya penarikan bisa dilihat pada alat weight indicator secara digital.

\section{DAFTAR PUSTAKA}

[1] Syarif, A. "Analisa Kekerasan Pisau Potong (Parang) pada Proses Penempaan (Forging)," Info-Teknik, vol. 9, no.2, pp. 117-124, 2008.

[2] Asfarizal, Jamil, A. "Pengaruh Sudut Dies Terhadap Penarikan Kawat Aluminium," Jurnal Teknik Mesin, vol. 2, no. 1, pp. 4148, 2012.

[3] Setyadi, I., Syawal, M. "Optimasi Proses Annealing pada Proses Fine Drawing untuk Memperbaiki Sifat Mekanis Produk Kawat Tembaga," Jurnal Sains Materi Indonesia, vol. 16, no. 4, pp. 164-172, 2015.

[4] Sari, A.C., Harsono, B. "Rancang Bangun Alat Pengukur Berat dan Dimensi Paket Berbasis Arduino Mega2560," Jurnal Elektro, vol. 10, no. 2, pp. 107-116, 2017.

[5] Debriand, R., Doloksaribu, M., Damanik, I. "Perancangan Timbangan Load Cell Type S," Jurnal Metal Indonesia, vol. 40, no. 1, pp. 34-39, 2018. 